\title{
The effects of exchange rate fluctuations on economic activity in Turkey
}

\author{
Magda Kandil ${ }^{\text {a,* }}$, Hakan Berument ${ }^{\mathrm{b}}$, N. Nergiz Dincer ${ }^{\mathrm{c}}$ \\ ${ }^{a}$ The Western Hemisphere Department, International Monetary Fund, 700 19th Street, N.W. Washington, DC 20431, USA \\ ${ }^{\mathrm{b}}$ Department of Economics, Bilkent University, Ankara, Turkey \\ ${ }^{\mathrm{c}}$ State Planning Organization, Ankara, Turkey
}

Received 17 January 2006; received in revised form 19 October 2006; accepted 15 December 2006

\begin{abstract}
The paper examines the effects of exchange rate fluctuations on real output, the price level, and the real value of components of aggregate demand in Turkey. The theoretical model decomposes movements in the exchange rate into anticipated and unanticipated components. Unanticipated currency fluctuations help to determine aggregate demand through exports, imports, and the demand for domestic currency, and aggregate supply through the cost of imported intermediate goods and producers' forecasts of relative competitiveness. Anticipated exchange rate appreciation has significant adverse effects, contracting the growth of real output and the demand for investment and exports, while raising price inflation. Unanticipated exchange rate fluctuations have asymmetric effects that highlight the importance of unanticipated depreciation in shrinking output growth and the growth of private consumption and investment, despite an increase in export growth. (C) 2007 Elsevier Inc. All rights reserved.
\end{abstract}

Keywords: Exchange rate fluctuations; Asymmetry; Supply and demand channels; Policy implications

JEL classification : F41; F31; E32; E31

\section{Introduction}

There has been an ongoing debate on the appropriate exchange rate policy in developing countries. The debate focuses on the degree of fluctuations in the exchange rate in the face of internal and external shocks. Exchange rate fluctuations are likely, in turn, to determine economic performance. In judging the desirability of exchange rate fluctuations, it becomes, therefore, necessary to evaluate their effects on output growth and price inflation. Demand and supply channels determine these effects.

\footnotetext{
* Corresponding author. Tel.: +1 202623 4696; fax: +1 2025894696.

E-mail addresses: mkandil@imf.org (M. Kandil), berument@bilkent.edu.tr (H. Berument), ndincer@dpt.gov.tr (N.N. Dincer).
} 
A depreciation (or devaluation) of the domestic currency may stimulate economic activity through the initial increase in the price of foreign goods relative to home goods. By increasing the international competitiveness of domestic industries, exchange rate depreciation diverts spending from foreign goods to domestic goods. As illustrated in Guittian (1976) and Dornbusch (1988), the success of currency depreciation in promoting trade balance largely depends on switching demand in the proper direction and amount, as well as on the capacity of the home economy to meet the additional demand by supplying more goods. ${ }^{1}$

While the traditional view indicates that currency depreciation is expansionary, the new structuralism school stresses some contractionary effects. Meade (1951) discusses this theoretical possibility. If the Marshall-Lerner condition is not satisfied, currency depreciation could produce contraction. ${ }^{2}$ Hirschman (1949) points out that currency depreciation from an initial trade deficit reduces real national income and may lead to a fall in aggregate demand. Currency depreciation gives with one hand, by lowering export prices, while taking away with the other hand, by raising import prices. If trade is in balance and the terms of trade are not changed, these price changes offset each other. But if imports exceed exports, the net result is a reduction in real income within the country. Cooper (1971) confirms this point in a general equilibrium model.

Diaz-Alejandro (1963) introduced another argument for contraction following devaluation. Depreciation may raise the windfall profits in export and import-competing industries. If money wages lag the price increase and if the marginal propensity to save from profits is higher than propensity to save from wages, national savings will go up and real output will decrease. Krugman and Taylor (1987) and Barbone and Rivera-Batiz (1987) have formalized the same views.

Supply-side channels further complicate the effects of currency depreciation on economic performance. Bruno (1979) and van Wijnbergen (1989) postulate that in a typical semiindustrialized country where inputs for manufacturing are largely imported and cannot be easily produced domestically, firms' input costs will increase following a devaluation. As a result, the negative impact from the higher cost of imported inputs may dominate the production stimulus from lower relative prices for domestically traded goods. Gylfason and Schmid (1983) provide evidence that the final effect depends on the magnitude by which demand and supply curves shift because of devaluation. ${ }^{3}$

To summarize, currency depreciation increases net exports and increases the cost of production. Similarly, currency appreciation decreases net exports and the cost of production. The combined effects of demand and supply channels determine the net results of exchange rate fluctuations on real output and price. ${ }^{4}$

This paper focuses on the relationship between exchange rate fluctuations and economic activity in Turkey. The contribution of the theory is in treating the process of forming rational

\footnotetext{
${ }^{1}$ Empirical support of this proposition for Group 7 countries over the 1960-1989 period is provided in Mendoza (1992).

2 The Marshall-Lerner condition states that devaluation will improve the trade balance if the devaluing nation's demand elasticity for imports plus the foreign demand elasticity for the nation's exports exceed 1 .

${ }^{3}$ Hanson (1983) provides theoretical evidence that the effect of currency depreciation on output depends on the assumptions regarding the labor market. Solimano (1986) studies the effect of devaluation by focusing on the structure of the trade sector. Agenor (1991) introduces a theoretical model for a small open economy and distinguishes between anticipated and unanticipated movement in the exchange rate. Examples of empirical investigations include Edwards (1986), Gylfason and Radetzki (1991), Rogers and Wang (1995), Hoffmaister and Vegh (1996), Bahmani (1991), Kamin and Rogers (2000), and Kandil and Mirzaie (2002, 2003).

${ }^{4}$ For an analytical overview, see Lizondo and Montiel (1989).
} 
forecasts of the exchange rate. Recent experiences of currency crises have brought to the forefront the importance of anchoring agents' forecasts in the design of an appropriate exchange rate policy. Hence, the theory aims to separate the effects of anticipated shifts in the exchange rate from unanticipated deviations around agents' forecasts. The theoretical investigation introduces a model that decomposes movements in the exchange rate into anticipated and unanticipated components using rational expectations. Anticipated movement in the exchange rate is assumed to vary with agents' observations of macro-economic fundamentals, which determine changes in the exchange rate over time. Deviation in the realized exchange rate from its anticipated value captures the unanticipated component of the exchange rate.

In this context, the output supplied varies with unanticipated price movements and the cost of the output produced. Anticipated exchange rate movements determine the cost of the output produced and producers' forecasts of relative competitiveness. In contrast, unanticipated exchange rate movements determine economic conditions in three directions: net exports, money demand, and the output supplied.

The solution of the model demonstrates the effects of demand and supply channels on the output and price responses to unanticipated changes in the exchange rate. Based on theory's solutions, empirical models are formulated for output, price, and the real value of components of aggregate demand in Turkey: consumption, investment, exports, and imports. The models incorporate demand and supply shifts as well as exchange rate shifts. Exchange rate fluctuations are assumed to be randomly distributed around a steady-state stochastic trend over time. This trend varies over time with agents' observations of macroeconomic fundamentals. Positive shocks to the real effective exchange rate indicate an unanticipated increase in the real foreign-currency price of domestic currency-that is, unanticipated currency appreciation. Similarly, negative shocks indicate unanticipated depreciation of the exchange rate.

The data under investigation are for Turkey over the sample period 1980-2004. The real effective exchange rate is constructed as a weighted average of the log value of the real price of the Turkish lira in terms of the currencies of its major trading partners. The weights represent the relative share of each trading partner in the total trade (exports and imports) for Turkey. Hence, the real exchange rate accounts for the relative prices in the domestic economy relative to the weighted average of foreign price in major trading partners. The relative price channel is important to the analysis of exchange rate fluctuations given the high inflationary experience in Turkey. Accordingly, the empirical investigation will combine the nominal exchange rate policy with movements in domestic price inflation relative to that of major trading partners to determine the implications of fluctuations in the real exchange rate on economic performance in Turkey.

The results clearly illustrate the different effects of anticipated and unanticipated shifts of the exchange rate on the macroeconomy in Turkey. Anticipated shifts have significant adverse effects, contracting the growth of real output and the demand for investment and exports, while raising price inflation. As producers anticipate loss of competitiveness, they shrink the output supply. This evidence emphasizes the role of rational forecasts in guiding production plans in Turkey. In contrast, unanticipated deviation of the realized exchange rate from agents' forecasts induce random fluctuations, with varying effects, on output growth, price inflation, and the growth of aggregate demand. Asymmetry highlights a more significant effect of unanticipated depreciation, which shrinks real output growth and the growth of real private demand on consumption and investment, despite higher exports. Asymmetry indicates that exchange rate fluctuations could have adverse effects on the economy in Turkey. The remainder of the paper is organized as follows. Section 2 presents the theoretical model. Section 3 discusses developments 
in Turkey. Section 4 outlines the empirical models and presents empirical results. The summary and conclusion are presented in Section 5.

\section{Theoretical background}

To motivate the empirical investigation, we draw on the implications of the theoretical model in Kandil and Mirzaie $(2002,2003)$. A summary of the theoretical implications is as follows. ${ }^{5}$ In the real world, stochastic uncertainty may arise on the demand or supply sides of the economy. Economic agents are assumed to be rational. Accordingly, rational expectations of demand and supply shifts enter the theoretical model. Economic fluctuations are then determined by unexpected demand and supply shocks impinging on the economic system.

The theoretical model incorporates exchange rate fluctuations of the domestic currency. Fluctuations are assumed to be realized around a steady-state trend that is consistent with variation in macro-economic fundamentals over time. Uncertainty enters the model in the form of disturbances to both aggregate demand and aggregate supply. Within this framework, aggregate demand is affected by currency depreciation through exports, imports, and the demand for domestic currency, and aggregate supply is affected through the cost of imported intermediate goods and producers' forecast of competitiveness. The model demonstrates theoretically that unanticipated currency depreciation may decrease real output growth, via the effect on the supply side. However, the relationship between unanticipated currency depreciation and aggregate demand makes the final outcome inconclusive.

Internal balance requires that aggregate demand for domestic output be equal to aggregate supply of domestic output at full employment. It is assumed that demand and supply shifts in the model are constructed of two components: anticipated (steady-state) component and an unanticipated (random) component. The solution of the model results in reduced form equations for real output, price, and components of aggregate demand (see Kandil and Mirzaie (2003) for details).

In theory, the combination of demand and supply channels indicates that real output depends on unanticipated movements in the exchange rate, the money supply, and government spending. ${ }^{6}$ In addition, supply-side channels establish that output varies with anticipated changes in the exchange rate.

Given demand-side channels, aggregate demand increases with an increase in government spending or the money supply, increasing output and price in the short-run.

The complexity of demand and supply channels may determine the results of exchange rate fluctuations as follows:

1. In the goods market, a positive shock to the exchange rate of the domestic currency (an unexpected appreciation) will make exports more expensive and imports less expensive. As a result, the competition from foreign markets will decrease the demand for domestic products, decreasing domestic output and price. ${ }^{7}$

\footnotetext{
${ }^{5}$ For similar theoretical models, see Agenor (1991). For other relevant references, see Buiter (1990).

${ }^{6}$ Shocks are assumed to fluctuate in response to domestic economic conditions or in response to external vulnerability, e.g., capital mobility or fluctuations in foreign reserves.

${ }_{7}$ Similarly, a depreciation of the exchange rate stimulates demand for exports, which triggers capital accumulation to produce tradable goods. The elasticity of supply to cope with the increased demand determines the allocation of the exchange rate shock between output growth and price inflation.
} 
2. In the money market, a positive shock to the domestic currency (an unexpected temporary appreciation) relative to anticipated value, prompts agents to hold less domestic currency and decreases the interest rate. This channel moderates the contraction of aggregate demand and, therefore, the reduction in output and price in the face of a positive exchange rate shock.

3. On the supply side, a positive shock to the exchange rate (an unanticipated appreciation) decreases the cost of imported intermediate goods, increasing domestic output and decreasing the cost of production and, hence, the aggregate price level.

4. On the supply side, a positive shock to the exchange rate (an unanticipated appreciation) decreases competitiveness and, therefore, producers' outlook of external demand. Output supply decreases as a result.

The net effect of currency appreciation on output growth and price inflation is determined by the dominant effect of demand or supply channels.

Since both anticipated and unanticipated variables enter the theoretical model, the solution captures dynamics attributed to agents' forecasts. Anticipated variables are, by construction, function of lagged variables that determine agents' information at the time of forming their forecasts. The empirical model replicates this solution and the forecasting technique captures necessary dynamics.

\section{Developments in the Turkish economy}

In the 1980-83 period, Turkey was governed by a military regime. In that period, the deteriorated public balances were relieved by the tight fiscal policy and suppressed wages; price controls were gradually removed and interest rates were gradually liberalized. On the other hand, the government followed an exchange rate policy that aimed at preventing the real exchange rate from appreciating, thereby supporting the export-led growth strategy. The import regime was gradually liberalized. ${ }^{8}$ Thereby, the 1980 's were the years of integration with the world economy for Turkey.

In 1984, a new government came to power and followed similar policies to that of the military government till 1988, except that public expenditures increased, causing public deficits. Moreover, tax policy was changed in 1985, resulting in a further deterioration in the public balances for which domestic lending became an effective tool for financing the public deficit. Higher public deficit necessitated the launching of the stabilization program in 1988. Stabilization policies were successful in decreasing the deficit but it could not prevent inflation from increasing. Finally, 1989 was a year of a crisis; elections were held; wages increased by $42 \%$, the inflation rate, which was around $40 \%$ in the $1980-88$ period, rose to near $80 \%$; and a new phase for the Turkish economy started.

Overall, between 1980 and 1989, exchange rate policy supported real depreciations and, thereby, export-led-growth strategy. Moreover, imports were liberalized by removing quotas and decreasing the tariffs, thereby increasing the share of imports to GDP. Till 1989, the economy grew well and high export growth proved to be the engine of growth. Owing to tight fiscal policy and suppressed wages, consumption growth slowed to below overall economic growth, resulting in an increase in the growth of domestic savings. Higher savings were necessary to finance the growth in investment and boost export-led growth.

\footnotetext{
${ }^{8}$ Quotas were removed and tariffs were reduced.
} 
In 1989, the capital account was liberalized and in 1990 Turkey adopted a convertibility policy for the Turkish lira, and a new era started in the Turkish economy. High capital inflows that were realized in the 1988-90 period led to an appreciation of the Turkish lira. Furthermore, the policy of the government (higher spending and high interest rates to finance the deficit) prevented the exchange rate from depreciating. By 1990, the Central Bank of Turkey (CBRT) increased interest rates to attract more capital inflows. During this period, a primary deficit was observed and the public sector borrowing requirement was financed with short-term domestic borrowing. With the increase in interest rates, the domestic debt stock grew to such a level that a debt-rollover problem arose. The expectations for a devaluation increased at the end of 1993. In January 1994, the CBRT abandoned the exchange rate policy and devalued the nominal exchange rate by $14 \%$. The devaluation of the currency continued until April 1994 and the total devaluation for this period reached $173 \%$ in nominal terms. Output declined by $6.2 \%$ in the same year. In April 1994, a new economic program with the IMF was brought into effect to overcome the financial crises.

On the growth side, 1990 was the year of the recovery. The liberalization of the capital account, coupled with higher government spending, contributed to economic growth. As a result of wage increases and real appreciation of the Turkish lira, consumption increased by $13 \%$. Overall, growth was around 9\% in 1990. The same trend did not continue in 1991. During the Gulf crisis surrounding Iraq's invasion of Kuwait, the Turkish economy was adversely affected by regional conditions, which slowed down economic growth. To stimulate economic growth, a depreciation of the exchange rate was necessary, which boosted export-led growth in 1992. In 1993, the continued inflow of capital resulted in currency appreciation and supported economic growth, particularly the growth of domestic spending on consumption and investment. Nonetheless, the continued accumulation of public debt reached a level that became unsustainable, resulting in a financial crisis in 1994. Uncertainty surrounding the crisis led to a contraction of real output by $6 \%$ in 1994 .

As Turkey engaged in the economic program with the IMF in 1994, a series of reforms and stabilization policies were in place and economic recovery was underway. Following integration into the Customs Union in 1996, trade liberalization was accelerated, resulting in an increase in both exports and imports. The continued increase in capital inflows in 1996-1997 provided external resources to finance the current account deficit. Concurrently, foreign reserve accumulation contributed to a loose monetary policy, which supported the growth of investment and the economy. Unfortunately, inflation increased as well.

Starting with the economic program in 1994, the exchange rate policy was designed to stabilize the real exchange rate. The CBRT depreciated the nominal exchange rate parallel to inflation expectations.

In 1998, the Russian crisis hit the Turkish economy and private investment and consumption, as well as capital inflows, decreased sharply. Nonetheless, Turkey experienced a positive growth rate, boosted by export growth and the increase in public spending on consumption and investment.

In 1999, the economy underwent through another recession due to the earthquake and the deterioration in public finance. In December 1999, Turkey adopted another disinflation program with the support of the IMF. The aim of the program was to decrease inflation to a single digit at the end of 2002. The exchange rate regime of the program was announced as the crawling peg regime. The CBRT declared an exchange rate basket path consisting of 1 US $\$+0.77$ Euro, and announced a daily depreciation rate, which added up to a cumulative of $20 \%$ by the end of 2000. 
The implementation of the 1999 program gave positive signals. The nominal Treasury bond auction interest rates fell from $96.4 \%$ in November $1999^{9}$ to $34.1 \%$ in January 2000. Consistently, inflation expectations decreased. The economy realized high capital inflows, which supported a high growth rate that reached $4.8 \%$ in the first half of 2000 . However, higher growth resulted in an increase in consumption and investment spending, which stimulated an increase in import growth. Subsequently, the current account deficit deteriorated and the external balance became fragile. Despite crawling depreciation, capital inflow and high domestic spending led to a real exchange rate appreciation, which adversely affected export growth. Subsequently, the banking sector increased its foreign currency denominated debt to a level that became risky for the system. With the sudden capital outflow in November 2000 , the banking sector crises broke out, which led to a significant loss of foreign reserves of the CBRT.

In February 2001, political instability further contributed to a deterioration of economic conditions. As the economic crisis deepened, the crawling exchange rate regime was abandoned. The nominal exchange rate depreciated $94 \%$ (the annual increase of the second quarter of 2001) and the output response was detrimental, declining by $9.4 \%$.

In May 2001, a new program based on a floating exchange rate regime, tight fiscal policy and structural reforms was implemented. Signs of recovery were observed in 2002; output grew by $7.8 \%$. The source of growth was exports and public expenditures. ${ }^{10}$ For the 2002-2004 period it can be said that Turkey has managed to diversify exports, which resulted in a significant increase in export growth, despite real appreciation of the Turkish lira. In support of economic reform, fiscal policy was tight, which contributed to a reduction in the inflation rate and interest rates. Hence, the primary engines of growth between 2002 and 2004 were export growth and the growth of domestic private absorption (private investment and consumption).Appendix A illustrates figures for the rates of change in major macroeconomic variables and shares to GDP of important components.

\section{Empirical investigation}

Developments in the Turkish economy over time clearly illustrate that changes in the exchange rate policy have played a major role in shaping up economic conditions. Our investigation will aim at providing a thorough analysis of the interaction between exchange rate fluctuations and the macroeconomy in Turkey. The empirical investigation analyzes annual timeseries data of real output, the price level and specific demand components in Turkey for the period 1980-2004. The data and sources are given in Appendix B.

The results of the unit root test suggest that all of the variables, except for prices, the capacity utilization rate, and the unemployment rate, include a unit-root but their first differences are stationary. Capacity utilization and the unemployment rate are stationary in level, whereas the second difference of prices is stationary. ${ }^{11}$

The empirical investigation follows the solution of the theoretical model in Kandil and Mirzaie (2002). Accordingly, dependent variables (real output, the price level, and specific

\footnotetext{
${ }^{9}$ There was no Treasury auction in December, 1999.

${ }^{10}$ Although tight fiscal policy was targeted in 2002, public expenditures could not be prevented due to elections held at the end of 2002.

11 The results are available upon request.
} 
Table 1

Real exchange rate model ${ }^{\mathrm{a}}$

\begin{tabular}{lccccccccc}
\hline & Constant & $D_{\mathrm{rs}_{t-1}}$ & $D_{\mathrm{rs}_{t-2}}$ & $D_{\mathrm{tb}_{t-1}}$ & $D_{\mathrm{tb}_{t-2}}$ & $D_{\mathrm{open}_{t-1}}$ & $D_{\mathrm{open}_{t-2}}$ & $d 1$ & $d 2$ \\
\hline$D_{\mathrm{rs}_{t}}$ & 0.05 & 0.41 & -0.10 & 1.40 & 1.14 & $-1.23^{\mathrm{b}}$ & 0.13 & $0.20^{\mathrm{b}}$ & $0.28^{\mathrm{b}}$ \\
& $(1.20)$ & $(1.49)$ & $(-0.04)$ & $(1.44)$ & $(0.26)$ & $(-2.43)$ & $(0.33)$ & $(2.04)$ & $(2.71)$ \\
$R^{2}$ & 0.66 & & & & & & & &
\end{tabular}

${ }^{a}$ Here, $D_{\mathrm{rs}_{t}}$ is the first-difference of the real exchange rate. The change in the trade balance to nominal GDP is denoted by $D_{\mathrm{tb}_{t}}$. The change in the ratio of the sum of exports and imports to GDP, which is an indicator for openness, is denoted by $D_{\text {open }_{t}} . d 1$ and $d 2$ are the dummy variables that take 1 in 1989 and 1997, respectively and 0 elsewhere.

${ }^{\mathrm{b}}$ Indicates significance at the $5 \%$ level.

demand components) fluctuate in response to major domestic determinants of macroeconomic fundamentals and the real exchange rate. Assuming rational expectation, aggregate demand shifts and exchange rate shifts are decomposed into anticipated and unanticipated components. Anticipated shifts vary with agents' observations of macroeconomic fundamentals. Unanticipated shifts are random transitory shocks that have symmetric distribution over time. Positive shocks to the exchange rate approximate unanticipated currency appreciation, while negative shocks approximate unanticipated currency depreciation. Shocks are defined as the difference between the realizations and the anticipated portion of the exchange rate.

\subsection{Empirical models}

To identify the anticipated and unanticipated components of the exchange rate, we construct a model for the real exchange rate. To decide on the explanatory variables in the equation, we follow a formal causality test in Granger sense for the theoretically related variables. ${ }^{12}$ Using annual data, the change of the exchange rate is regressed on two of its lags and two lags of all variables that may be relevant to movements in the exchange rate in theory. The final exchange rate equation accounts for statistically significant lags and is presented in Table $1 .^{13}$

The residual of the above equation is the unanticipated component of the exchange rate, i.e., the exchange rate shock. The residual satisfies conditions for rationality, i.e., it is serially uncorrelated and orthogonal to all variables that determine agents' forecasts of the exchange rate, as they appear in the empirical model. Coefficients on the right-hand side indicate that an improvement in the trade balance leads to an appreciation of the exchange rate, although the relationship is not statistically significant. The real exchange rate depreciates in a more open economy. In 2004, the share of imports to GDP reached 35\% while the share of exports to GDP reached $28 \%$. Given the relatively higher share of imports, compared to exports, the increased openness depreciates the exchange rate significantly. The structural break points, captured by the dummies on the right-hand side, indicate an increase in the real effective exchange rate in 1989 and in 1997 that could not be explained by the explanatory variables. Recall 1989 was a crisis year and the inflation rate rose by $80 \%$. Inflation was also high in 1997 due to the significant capital inflow to finance the current account deficit.

\footnotetext{
12 The results are available upon request.

13 The necessary diagnostic tests are performed for the exchange rate model and the following models. Results are available upon request.
} 
To analyze the asymmetric effects of exchange rate shocks on the relevant macroeconomic variables, we decompose the exchange rate shock to its positive and negative components, as defined for joint estimation, following the suggestions of Cover (1992) as follows:

$$
\begin{aligned}
& \operatorname{neg}_{t}=-0.5\left\{\operatorname{abs}\left(D_{\mathrm{rs}_{t}}\right)-D_{\mathrm{rs}_{t}}\right\} \\
& \operatorname{pos}_{t}=0.5\left\{\operatorname{abs}\left(D_{\mathrm{rs}_{t}}\right)+D_{\mathrm{rs}_{t}}\right\}
\end{aligned}
$$

where, $D_{\mathrm{rs} t}$ is the exchange rate shock and neg ${ }_{t}$ and $\operatorname{pos}_{t}$ are the negative and positive components of the shock or, to express it differently, unexpected depreciation and appreciation of the exchange rate.

Over time, it is assumed that real output growth, price inflation and components of aggregate demand fluctuate in response to changes in aggregate domestic demand, and exchange rate shocks. In addition, given the importance of fluctuations in the energy price to regional economic conditions, we account for changes in the energy price in the empirical model.

The model specification is based on the results of the test for non-stationarity of real output. ${ }^{14}$

$$
D_{y_{t}}=A_{0}+A_{1} D_{\mathrm{O}_{t}}+A_{2} D_{\mathrm{m}_{t}}+A_{3} D_{\mathrm{g}_{t}}+A_{4} E_{t-1} D_{\mathrm{rs}_{t}}+A_{8}\left(D_{\mathrm{rs}_{t}}-E_{t-1} D_{\mathrm{rs}_{t}}\right)+v_{t}^{y}
$$

The test results are consistent with non-stationary real output for Turkey. Given these results, the empirical model of real output is specified in first difference form where $D(\cdot)$ is the firstdifference operator. ${ }^{15}$ Accordingly, all variables in the model enter in first-difference form. The unexplained residual of the model is denoted by $v_{t}^{y}$.

Let $\mathrm{o}_{t}$ be the $\log$ value of the energy price. In an oil-importing country, output growth is expected to vary negatively with changes in the energy price. Accordingly, $A_{1}<0$. Nonetheless, Turkey is surrounded by oil-producing countries (Iran and Arab Gulf countries). It is possible that Turkey would enjoy a positive spillover effect from a boom in neighboring countries in the wake of an increase in the energy price. Two sources of domestic policies, government spending and the money supply, approximate demand shifts, where $\mathrm{g}_{t}$ and $\mathrm{m}_{t}$ denote the $\log$ values of government spending and the money supply.

Finally, anticipated appreciation of the real exchange rate determines the cost of the output supplied. Let $\mathrm{rs}_{t}$ be the log value of the real exchange rate. ${ }^{16}$ Accordingly, a rise in the exchange rate indicates real appreciation of the domestic currency. As producers anticipate a lower cost of imported intermediate goods, in the face of currency appreciation, they increase the output supplied. Nonetheless, it is possible that anticipated appreciation may trigger anticipation of a loss in competitiveness and, therefore, a decline in external demand, forcing a reduction in output supply. By construction, anticipated change in the exchange rate are function of lagged variables in the economic system. Accordingly, adjustments of real output growth to anticipated shifts capture intertemporal dynamics over time.

Unanticipated change in the exchange rate is likely, however, to determine both aggregate demand and supply. ${ }^{17}$ Unanticipated currency appreciation, a shock to the exchange rate,

\footnotetext{
${ }^{14}$ For details, see Kwiatkowski, Phillips, Schmidt, and Shin (1992). Non-stationarity indicates that, real output follows a random-walk process. Upon first-differencing, the resulting series is stationary, which is the domain of demand and supply shifts, as specified in theory.

${ }^{15}$ Given the non-stationarity of the estimated dependent variables, the empirical models are estimated in first-difference form.

${ }^{16}$ This measure captures shifts attributed to the nominal exchange rate and the foreign price of imports in theory.

${ }^{17}$ Unanticipated currency appreciation may be the result of unanticipated shock that moves the exchange rate relative to its expected value. Alternatively, unanticipated appreciation may be consistent with an overvalued currency compared to agents' expectations that have adjusted downward in view of underlying macroeconomic fundamentals.
} 
decreases the cost of buying intermediate goods, increasing the output supplied. Concurrently, appreciation decreases net exports and the demand for domestic currency. The final effect remains indeterminate on aggregate demand, output, and price.

To demonstrate fluctuations in the output price, an empirical model is specified as follows:

$$
D_{\mathrm{p}_{t}}=B_{0}+B_{1} D_{\mathrm{O}_{t}}+B_{2} D_{\mathrm{m}_{t}}+B_{3} D_{\mathrm{g}_{t}}+B_{4} E_{t-1} D_{\mathrm{rs}_{t}}+B_{5}\left(D_{\mathrm{rs}_{t}}-E_{t-1} D_{\mathrm{rs}_{t}}\right)+v_{t}^{\mathrm{p}}
$$

Based on test results, output price is evident to be non-stationary. Accordingly, the empirical model is specified in first-difference form. Energy price shifts increase the cost of the output produced and, hence, prices. Nonetheless, a positive spillover effect of an increase in the energy price on output growth may have a deflationary effect on price. Demand shifts increase price inflation. Accordingly, $B_{2}, B_{3}>0$

Given that the effect of anticipated currency appreciation maybe positive or negative on the output supplied, price inflation may increase or decrease. ${ }^{18}$ An unanticipated appreciation of the domestic currency (a positive shock to the exchange rate) may increase (cheaper cost of imported inputs) or decrease (Loss of competitiveness) the output supplied and may decrease (net exports effect) or increase (money demand effect) aggregate demand. The reduction in demand coupled with an increase in supply are deflationary while the other channels increase price inflation.

In addition to the empirical models for real output growth and price inflation, we replicate the same models to explain cyclical fluctuations in components of aggregate demand, real growth of private consumption, $D_{\mathrm{c}}$, real growth of private investment, $D_{i}$, real growth of exports, $D_{x}$, and real growth of imports, $D_{\mathrm{im}}$.

In all empirical models, we test the significance of structural break using four dummy variables: a dummy variable for the economic crisis in 1988, a dummy variable for the Gulf crisis in 1992, a dummy variable for integration in the Customs Union in 1996, and a dummy variable for the earthquake in 1999.

The empirical models are estimated jointly along with the equation that describes agents' forecast of the exchange rate using 3SLS. To account for endogenous variables, instrumental variables are used in the estimation of empirical models.

\subsection{Empirical results}

To analyze the asymmetric effects of exchange rate shocks on output, the price level, and components of aggregate demand, we estimate empirical models that control for other policy variables. In this respect, the variables under consideration are modeled, as presented in Table 2. The explanatory variables in the models are the growth rate of each of government spending, the money supply, energy prices, the expected change in the exchange rate, unexpected exchange rate appreciation (positive shocks) and depreciation (negative shocks), and the necessary dummies to control for structural breaks.

\subsubsection{Fluctuations in real output growth}

The first column, under dependent variables, indicates fluctuations in real output growth. The growth of government spending is significant in stimulating real output growth in the current period. The growth of the money supply appears to be counter-cyclical. That is, additional

\footnotetext{
${ }^{18}$ Anticipated shifts in the real exchange rate are function of lagged values of variables that enter the forecast equation, including its own lags. Hence, lagged values of domestic price are captured in anticipated currency shifts.
} 
Table 2

Models of output, prices and components of aggregate demand

\begin{tabular}{|c|c|c|c|c|c|c|}
\hline Variables & $D_{y_{t}}$ & $D_{\mathrm{p}_{t}}$ & $D_{\mathrm{c}_{t}}$ & $D_{i_{t}}$ & $D_{x_{t}}$ & $D_{\mathrm{im}_{t}}$ \\
\hline Constant & $0.12(5.66)^{\mathrm{a}}$ & $0.05(1.28)$ & $0.09(2.58)^{\mathrm{a}}$ & $0.45(3.49)^{\mathrm{a}}$ & $0.09(1.70)$ & $0.22(1.22)$ \\
\hline$D_{\mathrm{g}_{t}}$ & $0.54(6.34)^{\mathrm{a}}$ & $-0.31(-1.39)$ & $0.74(3.75)^{\mathrm{a}}$ & $2.81(3.17)^{\mathrm{a}}$ & $-1.09(-4.30)^{\mathrm{a}}$ & $0.63(0.77)$ \\
\hline$D_{g_{t-1}}$ & $0.10(1.31)$ & $0.44(2.23)^{\mathrm{a}}$ & $-0.12(-0.71)$ & $-0.07(-0.12)$ & $0.12(0.43)$ & $-0.50(-0.84)$ \\
\hline$D_{\mathrm{m}_{t}}$ & $-0.30(-7.87)^{\mathrm{a}}$ & $0.58(6.89)^{\mathrm{a}}$ & $-0.19(-2.80)^{\mathrm{a}}$ & $-0.65(-2.87)^{\mathrm{a}}$ & $-0.20(-2.78)^{\mathrm{a}}$ & $-0.49(-1.66)$ \\
\hline$D_{\mathrm{m}_{t-1}}$ & $0.21(6.04)^{\mathrm{a}}$ & $0.21(2.79)^{\mathrm{a}}$ & $0.15(2.05)^{\mathrm{a}}$ & $0.15(0.61)$ & $0.18(1.81)$ & $0.34(0.73)$ \\
\hline$D_{\mathrm{o}_{t}}$ & $0.64(11.19)^{\mathrm{a}}$ & $-0.53(-2.43)^{\mathrm{a}}$ & $0.78(3.39)^{\mathrm{a}}$ & $3.30(4.75)^{\mathrm{a}}$ & $0.28(1.26)$ & $0.64(0.60)$ \\
\hline$D_{\mathrm{o}_{t-1}}$ & $-0.13(-1.56)$ & $0.71(3.24)^{\mathrm{a}}$ & $-0.15(-0.79)$ & $-1.03(-0.81)$ & $-0.69(-2.51)^{\mathrm{a}}$ & $-0.54(-0.74)$ \\
\hline$E_{t-1} D_{\mathrm{rs}_{t}}$ & $-0.30(-5.12)^{\mathrm{a}}$ & $0.65(4.51)^{\mathrm{a}}$ & $-0.25(-1.88)$ & $-0.99(-2.29)^{\mathrm{a}}$ & $-0.40(-3.24)^{\mathrm{a}}$ & $-0.06(-0.09)$ \\
\hline$E_{t-2} D_{\mathrm{rs}_{t-1}}$ & $-0.17(-3.54)^{\mathrm{a}}$ & $-0.01(-0.07)$ & $-0.05(-0.56)$ & $-1.20(-2.75)^{\mathrm{a}}$ & 0.17 (1.57) & $-0.07(-0.11)$ \\
\hline $\operatorname{pos}_{t}$ & $-0.33(-1.72)$ & $-0.09(-0.24)$ & $-0.42(-1.20)$ & $-0.84(-0.65)$ & $0.14(0.32)$ & $0.10(0.04)$ \\
\hline $\operatorname{pos}_{t-1}$ & $-0.09(-0.60)$ & $-1.15(-2.59)^{\mathrm{a}}$ & $-0.23(-0.51)$ & $-1.40(-1.12)$ & $0.34(0.67)$ & $-2.05(-1.31)$ \\
\hline $\operatorname{neg}_{t}$ & $0.19(0.21)$ & $0.39(1.26)$ & $0.13(0.56)$ & $-0.16(-0.19)$ & $-0.22(-0.59)$ & $0.07(0.10)$ \\
\hline $\operatorname{neg}_{t-1}$ & $0.39(11.13)^{\mathrm{a}}$ & $0.18(0.98)$ & $0.51(2.67)^{\mathrm{a}}$ & $2.46(2.13)^{\mathrm{a}}$ & $-0.80(-2.54)^{\mathrm{a}}$ & $0.45(0.72)$ \\
\hline$d 1$ & $-0.06(-4.06)^{\mathrm{a}}$ & $0.16(4.19)^{\mathrm{a}}$ & & & & \\
\hline$d 2$ & & $0.08(2.45)^{\mathrm{a}}$ & & $0.17(2.34)^{\mathrm{a}}$ & & \\
\hline$d 3$ & & $-0.13(-3.71)^{\mathrm{a}}$ & & & $0.10(3.86)^{\mathrm{a}}$ & $0.27(3.32)^{\mathrm{a}}$ \\
\hline$d 4$ & $-0.15(-12.20)^{\mathrm{a}}$ & & $-0.13(-3.62)^{\mathrm{a}}$ & $-0.55(-4.48)^{\mathrm{a}}$ & & \\
\hline$R^{2}$ & 0.98 & 0.99 & 0.90 & 0.89 & 0.90 & 0.85 \\
\hline Asym & $12.64^{\mathrm{a}}$ & $5.16^{\mathrm{a}}$ & $2.96^{\mathrm{a}}$ & $3.57^{\mathrm{a}}$ & $8.08^{\mathrm{a}}$ & 0.49 \\
\hline
\end{tabular}

The explanatory variables of the model are the growth rates of $\mathrm{g}_{\mathrm{t}}$ for government spending, $m_{t}$ for the money supply, $\mathrm{o}_{t}$ for energy prices, $E_{t-1} D_{\mathrm{rs}_{t}}$ for expected change in the real exchange rate, pos $_{t}$ for unanticipated exchange rate appreciation, neg $_{\mathrm{t}}$ for unanticipated exchange rate depreciation, and dummy variables for structural breaks, $d 1$ for the economic crisis in $1988, d 2$ for the Gulf crisis in 1992, $d 3$ for integration in the Customs Union in 1996, and $d 4$ for the earthquake in $1999 . D_{y}$ is real output growth, $D_{\mathrm{p}}$ is price inflation, $D_{\mathrm{c}}$ is growth of real consumption, $D_{i}$ is growth of real investment, $D_{x}$ is growth of real exports and $D_{\mathrm{m}}$ is growth of real imports.

${ }^{a}$ Indicates significance at the 5\% level, Asym is the result of the Wald test where the null hypothesis is no asymmetry.

liquidity maybe targeting a slowdown in the economy. Real output growth appears to pick up in response to lagged growth of the money supply.

It is interesting to note that an increase in the oil price has a positive effect on output growth in Turkey. This evidence indicates a positive spillover effect from neighboring oil-producing countries (Iran and Arab Gulf countries) on output growth in Turkey.

Anticipated appreciation of the exchange rate, current and lagged, has a negative effect on output growth in Turkey. This indicates a dominant effect of the demand channel on output growth. As producers anticipate exchange rate appreciation and loss of competitiveness, they shrink the output supply. Apparently, anticipated appreciation is more important compared to unanticipated appreciation, as the latter is not significant in explaining real output growth. Lagged unanticipated depreciation (a negative exchange rate shock) has a positive effect on output growth. Unexpected depreciation increases the cost of imported inputs, forcing reduction in the output supply. The significant Wald test statistic indicates asymmetric effects of unanticipated currency appreciation and depreciation on output growth in Turkey.

As illustrated in Fig. 1, unanticipated exchange rate depreciation in 1994 and 2001 correlates with a reduction in real output growth.

There are two significant dummies in the output equation, indicating a reduction in output growth in 1988 and in 1999. The first observation surrounds the beginning of the stabilization program that led to a significant reduction in government spending to contain the budget deficit. The second observation marks the 1999 earthquake. 


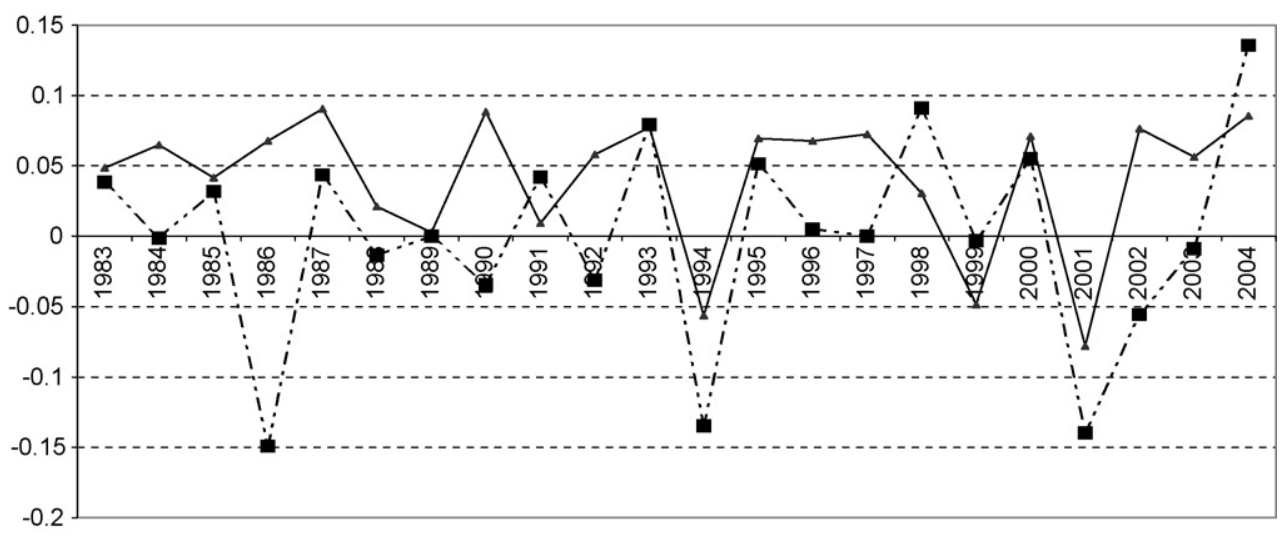

Fig. 1. Output growth and unexpected real exchange rate shocks.

\subsubsection{Fluctuations in price inflation}

The growth of government spending (lagged) has a significant positive effect on price inflation. While contemporaneous growth of government spending increases output growth, capacity limitation necessitates an increase in price inflation in the following period.

The inflationary effects of monetary growth are evident and significant, both in the current and lagged period. Liquidity stimulates additional demand and fuels price inflation. Consistent with capacity limitations, monetary growth fuels price inflation, without stimulating output growth in the current period. Having relaxed capacity constraints in the following period, monetary growth stimulates output growth, with additional increase in price inflation.

The effects of an increase in the energy price are interesting in explaining price inflation. The positive spillover effect on output growth correlates with a contemporaneous reduction in price inflation. In the following period, higher oil price increases cost and, therefore, price inflation.

Anticipated exchange rate appreciation raises price inflation. This may reflect a high degree of persistence in price inflation. Expected changes in the real effective exchange rate are function of its lags, which are, in turn, dependent on lagged price inflation. The positive effect of anticipated appreciation on price inflation indicates close adjustment of price inflation to its lagged values.

Unanticipated appreciation of the exchange rate slows down price inflation in the next period. This is evident by the negative and statistically significant response of price inflation to lagged exchange rate appreciation, i.e., the lagged positive shock. Unanticipated appreciation slows down the demand for exports and decreases aggregate demand. Additionally, unanticipated appreciation decreases the cost of imported inputs and increases aggregate supply. ${ }^{19}$

Wald test statistic indicates asymmetric effects of exchange rate shocks (positive and negative) on price inflation in Turkey.

The graph in Fig. 2 illustrates a few observations, where currency appreciation appears to have been followed by a reduction in price inflation $(1985,1995,1998,2000,2004)$.

\footnotetext{
19 The import price data exist till 1994 for Turkey. In the face of unanticipated currency appreciation, for the periods 1997, 1999-2000 and 2002-2003, import prices, mostly import prices of consumption goods decreased. Moreover, the composition of imports suggests consumption of imported goods increases with respect to unexpected appreciation. The share of consumption goods constitutes $13 \%$ of total imports in 2004. This share increases in the years when unexpected appreciation is observed.
} 


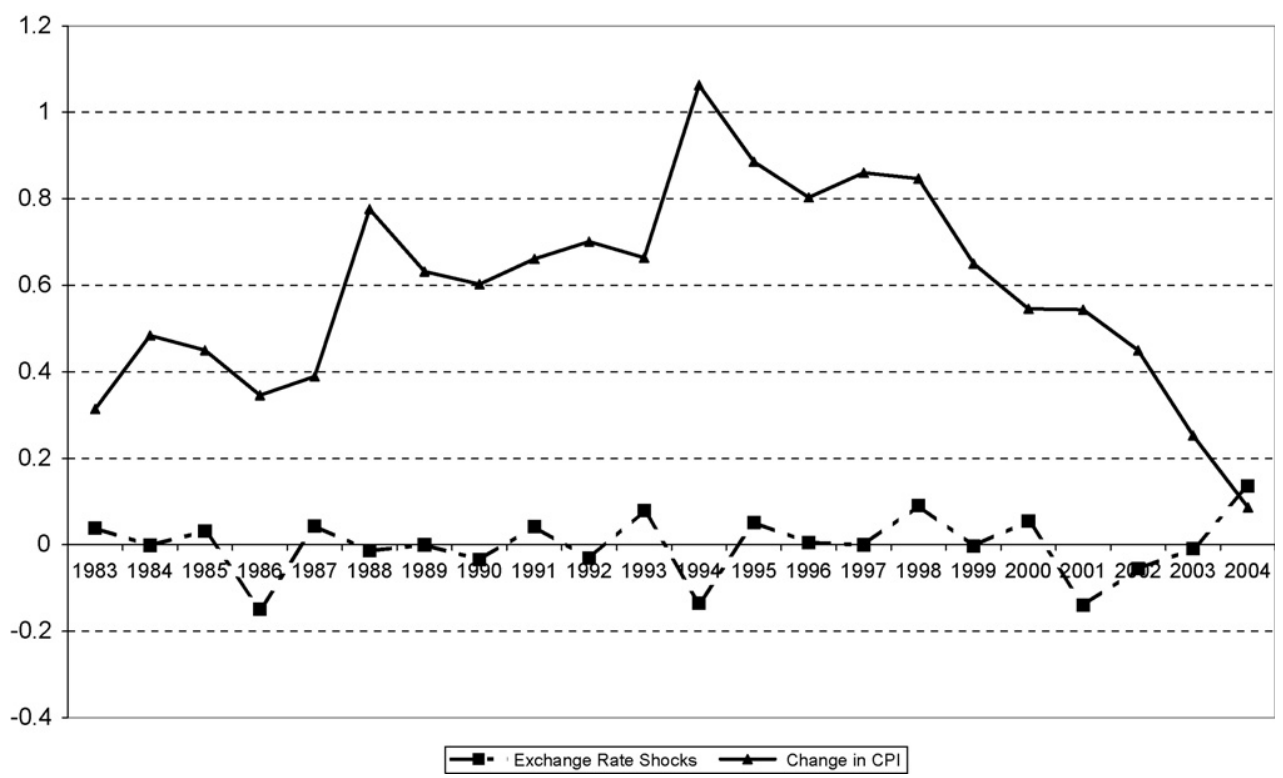

Fig. 2. CPI inflation and unexpected real exchange rate shocks.

Structural break dummies indicate a significant increase in price inflation in 1988 and in 1992 and a significant reduction in 1996. During the 1989 crisis, price inflation increased by $80 \%$. During the 1991 Gulf crisis, the Turkish economy was adversely affected by regional conditions, which fueled price inflation. The integration into the Customs Union in 1996 resulted in removal of tariffs on imports, decreasing price inflation.

\subsubsection{Fluctuations in consumption growth}

To analyze the effects of exchange rate fluctuations on components of aggregate demand, the third column in Table 2 indicates fluctuations in real consumption with policy variables and fluctuations in the exchange rate.

Consistent with the effect of government spending on output growth, private consumption increases significantly with the growth of government spending. Failure of monetary growth to stimulate growth in the current period is further supported by the negative and significant sign on consumption. In the following period, growth picks up and, therefore, consumption demand.

The positive spill over effect of an increase in the energy price on growth is consistent with an increase in real consumption demand. As for exchange rate fluctuations, consumption does not vary significantly with anticipated changes in the exchange rate. Unanticipated appreciation is also insignificant on real consumption growth. Unanticipated depreciation (lagged) has a positive significant effect on growth and, therefore, consumption demand. In the face of unexpected depreciation, consumers decrease consumption of durable goods, especially imported luxury goods. $^{20}$

\footnotetext{
${ }^{20}$ Consumption of non-durables constitutes $60 \%$ of total consumption, and is more-or-less stable for Turkey, i.e., it does not change much with output growth, the exchange rate, or price movements. However, consumption of durable goods is fluctuating and contributes to asymmetry in the behavior of total consumption with respect to unexpected exchange rate fluctuations.
} 


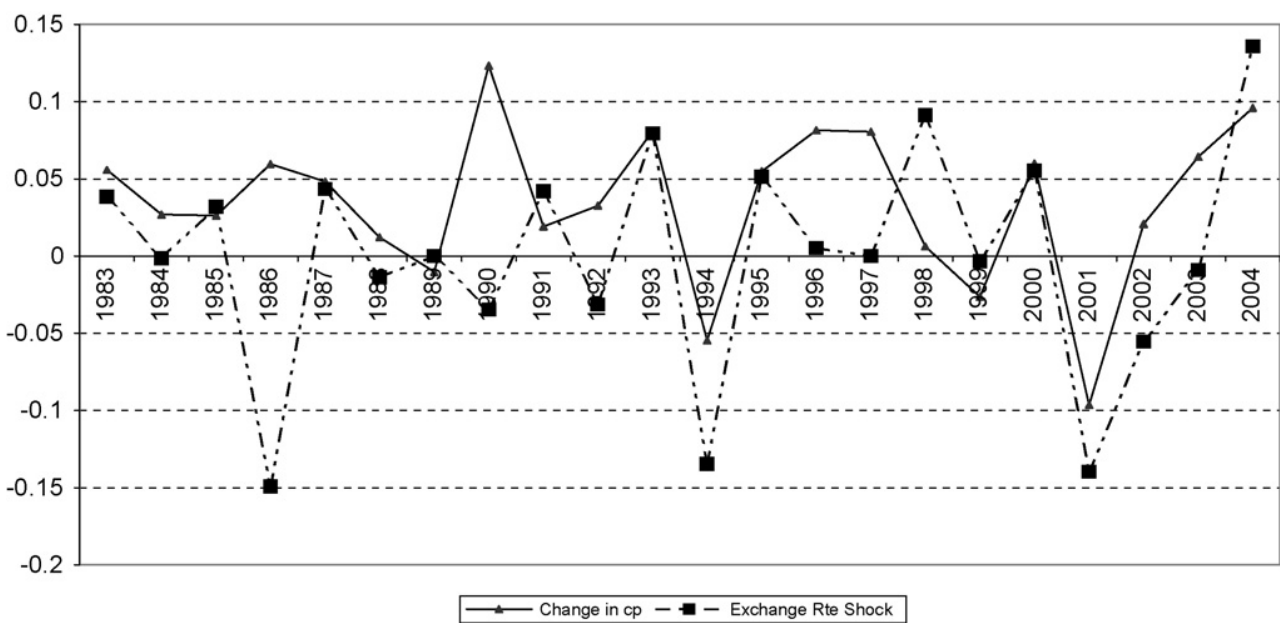

Fig. 3. Consumption growth and unexpected real exchange rate shocks.

The Wald test statistic indicates significant asymmetry in the response of consumption growth to positive and negative exchange rate shocks. Further, the dummy variable indicates significant reduction in consumption growth in 1999, around the earthquake.

Fig. 3 illustrates fluctuations in consumption demand with exchange rate shocks. Currency depreciation appears to have led to a decrease in consumption growth in 1988, 1989, 1994, 1999 and 2001.

\subsubsection{Fluctuations in investment growth}

Consistent with the effects of government spending in stimulating growth, investment demand increases significantly. In contrast, failure of monetary growth to stimulate growth is also consistent with a negative and significant effect on investment demand. The positive spill over effect of an increase in the oil price on growth is consistent with a positive significant effect on investment demand.

Both current and lagged anticipated appreciation have negative significant effects on investment growth. This confirms the negative effect of anticipated appreciation on the supply side of the economy. As agents expect a reduction in external demand, the demand for investment decreases.

The lagged value of the negative shock to the exchange rate (unanticipated depreciation) has a positive and significant effect on investment demand. Unanticipated depreciation increases the cost of imports and decreases investment demand.

The Wald test indicates significant asymmetry in the effects of positive and negative exchange rate shocks on investment. Fig. 4 indicates fluctuations in investment growth with exchange rate shocks. Unanticipated depreciation decreased investment demand in 1994, 2001, and 2002.

Parameters of structural break indicate significant increase in investment demand during the Gulf crisis in 1991. This could be a reflection of an increase in capital inflow from neighboring countries. In contrast, there was a significant decrease in investment growth surrounding the earthquake in 1999.

\subsubsection{Fluctuations in export growth}

In Table 2, the increase in government spending has a negative and significant effect on export demand. Higher government spending increases the deficit and raises the interest rate (see 


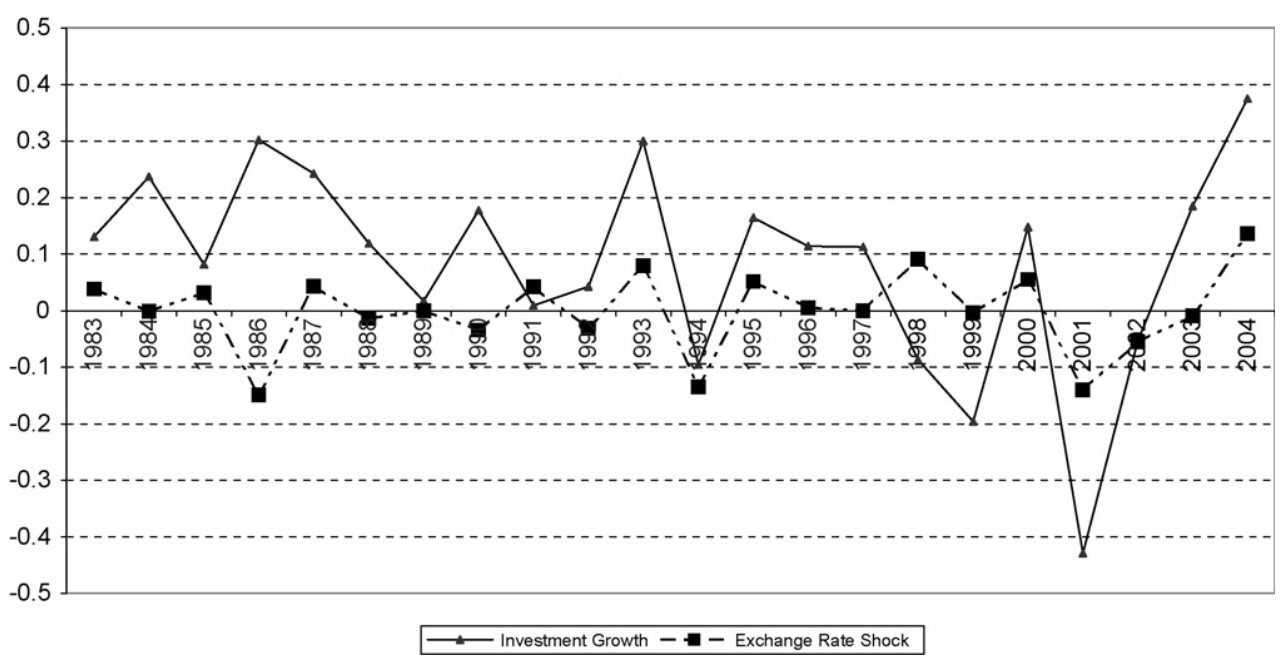

Fig. 4. Investment growth and unexpected real exchange rate shocks.

above). As Turkey moved to liberalize the capital account, the inflow of capital led to currency appreciation, depressing competitiveness and export demand.

Monetary growth does not stimulate output growth and, therefore, export growth. Lagged energy price increase decreases export demand. Higher energy price increases cost, resulting in higher price inflation (with a lag). The loss of competitiveness, through this channel, has a negative significant effect on export growth.

Anticipated appreciation of the exchange rate has a negative and statistically significant effect on export growth in Turkey. Anticipated appreciation decreases competitiveness, shrinking demand and switching production in favor of non-tradables. Lagged unanticipated depreciation has a negative and significant effect on export growth. Unanticipated depreciation stimulates export growth, although with a lag.

Wald test statistic is significant regarding asymmetry in the effects of exchange rate shocks on export growth. This result would be interpreted as the macroeconomic consequence of microeconomic theories. Among the micro-based studies, there are a few studies discussing the asymmetric effects of exchange rate shocks. Most of them discuss these asymmetric effects within a micro-economic modeling framework. Froot and Klemperer (1989) and Knetter (1989) point out that the asymmetric response of stock prices to currency movements may occur due to asymmetric pricing-to-market (PTM) behavior. When the domestic currency appreciates, exporting firms with a market share objective do not permit local currency prices to increase because of the risk of losing their share, so they decrease their profit margins. Hence, exports do not decrease. On the other hand, under currency depreciations, exporting firms with a market share objective maintain, rather than increase, their profit margins as a result of their focus on sales volume. Therefore, exports increase with the increase in the market share. Other studies supporting the same arguments are Marston (1990) and Goldberg (1995).

In Fig. 5, negative exchange rate shocks stimulated export demand in 1984, 1988, 1990, 1992, 1994, 2001, and 2002. Structural dummy is significant regarding the increase in export growth following integration into the Customs Union in 1996. 


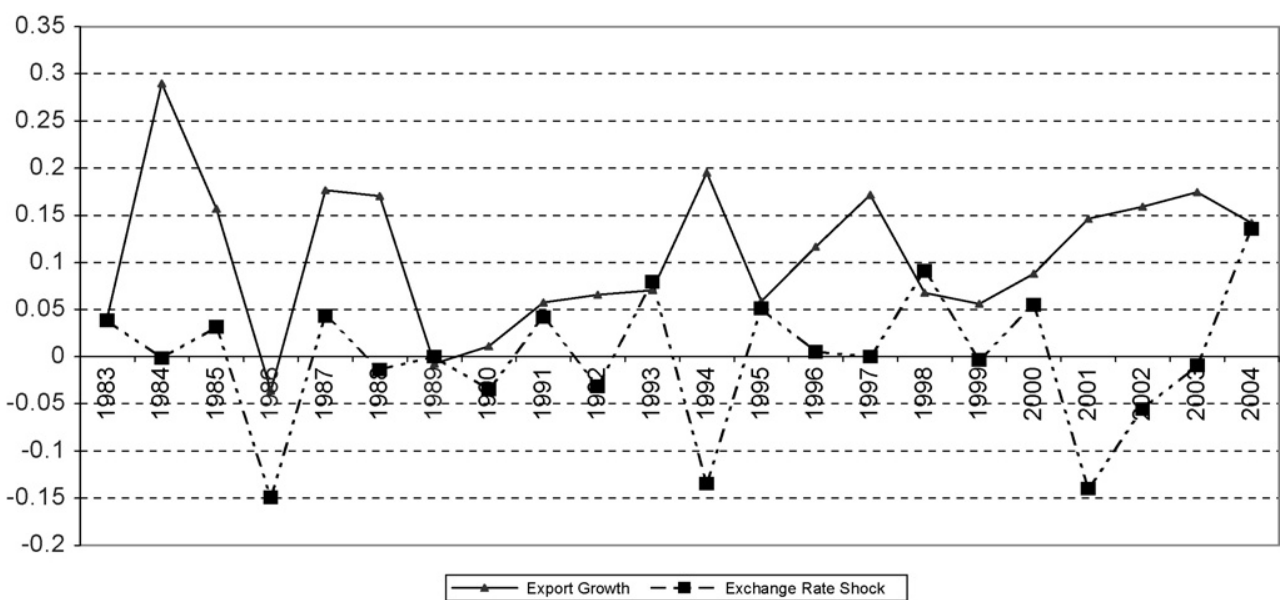

Fig. 5. Export growth and unexpected real exchange rate shocks.

\subsubsection{Fluctuations in import growth}

The last column in Table 2 tracks fluctuations in import growth with domestic policies and exchange rate fluctuations. All variables are statistically insignificant in the empirical model. As variables in the model are included to measure cyclicality, lack of statistical significance indicates that imports follow a structural process that does not vary in the short-run with determinants of cyclicality. Structural dummy indicates a significant increase in import growth following integration into the Customs Union in 1996.

Wald test results suggest that the effects of unexpected exchange rate shocks on imports are not asymmetric. That is, the effects of both positive and negative shocks to the exchange rate are insignificant. Fig. 6 illustrates movements in import growth with exchange rate shocks.

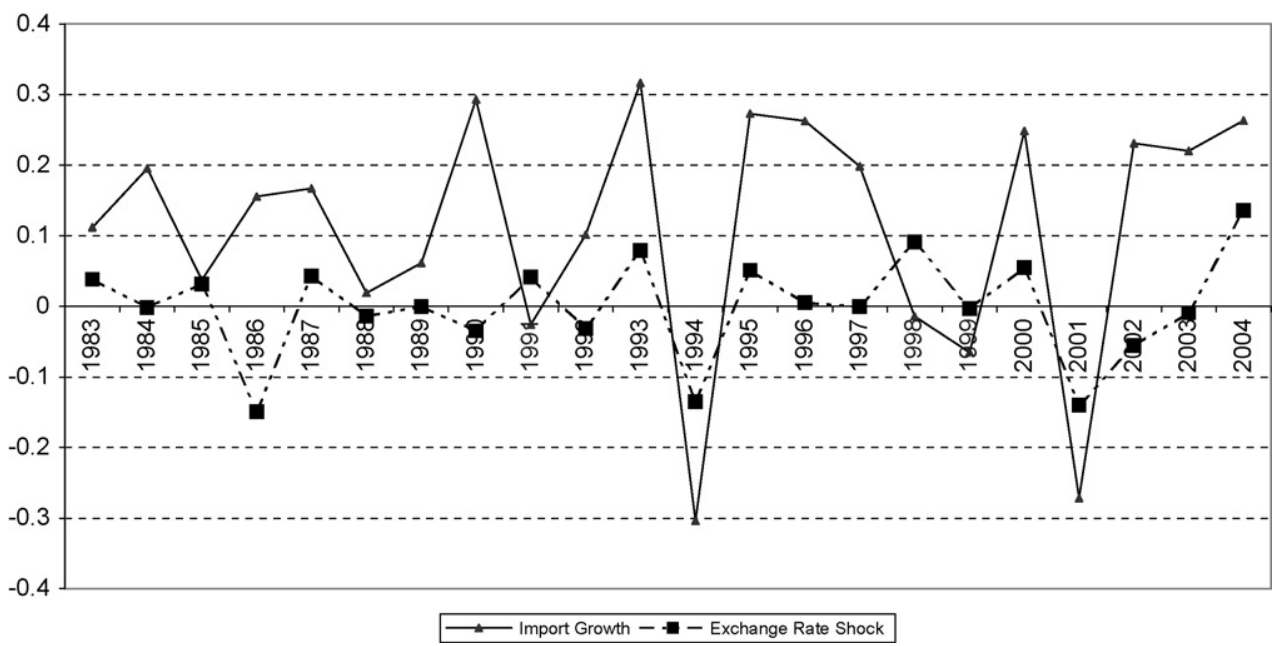

Fig. 6. Import growth and unexpected real exchange rate shocks. 


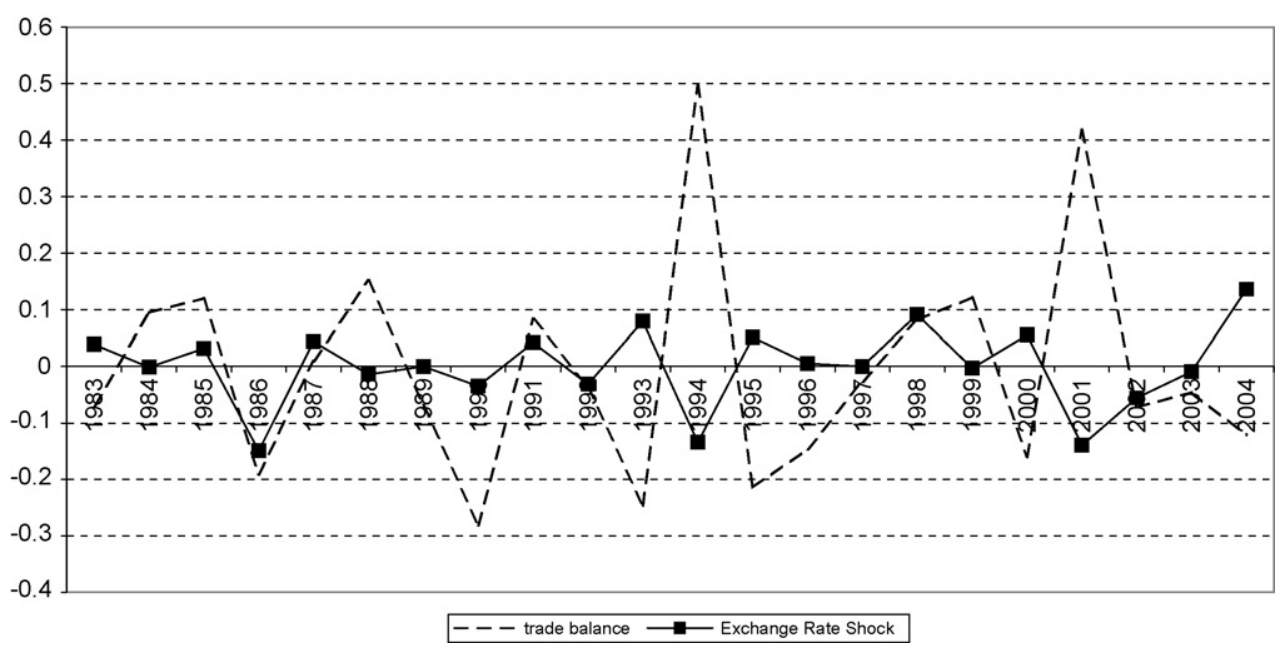

Fig. 7. Trade balance and unexpected real exchange rate shocks.

\subsubsection{Fluctuations in trade balance}

Having analyzed the effects of exchange rate fluctuations on export and import growth, Fig. 7 illustrates fluctuations in the trade balance with exchange rate shocks. An appreciation of the exchange rate correlates with a deterioration in the trade balance in 1988, 1994, 1999, and 2001. A depreciation of the exchange rate correlates with an improvement in the trade balance in 1993, 1995, 2000, and in 2004.

\section{Summary and conclusion}

The analysis has focused on the effects of exchange rate fluctuations using annual data for Turkey between 1980 and 2004. To that end, a theoretical rational-expectations model that decomposes movements in the exchange rate into anticipated and unanticipated components is used. Anticipated changes in the exchange rate enter the production function through the cost of imported goods and producers' forecasts of relative competitiveness. Unanticipated currency fluctuations determine aggregate demand through exports, imports, and the demand for domestic currency, and determine aggregate supply through the cost of imported intermediate goods.

Let the exchange rate be the real price of the domestic currency in terms of a weighted average of the currencies of major trading partners. Anticipated movements in the exchange rate are assumed to vary with agents' observations of macro-economic fundamentals determining changes in the exchange rate over time. A positive shock to the exchange rate, an unanticipated appreciation of the domestic currency, decreases net exports and money demand and increases the output supplied. Based on the strength of each channel, the combined effects of demand and supply channels may determine the direction of output and price adjustments in the face of currency fluctuations.

In addition to fluctuations in the exchange rate, the empirical model accounts for the growth of government spending, the growth of the money supply, the change in the energy price, and a number of dummy variables for structural break. The dependent variables under investigation are 
real output growth, price inflation, and the growth in components underlying aggregate demand: real consumption, real investment, real exports, and real imports. Major highlights of the results are as follows.

The growth of government spending is an important determinant of economic conditions in Turkey. An increase in government spending stimulates real output growth and private demand for consumption and investment. Concurrently, the increase in the interest rate may result in an increase in capital inflows that appreciates the exchange rate. Through this channel, the increase in government spending decreases the growth of real exports. Overall, the increased demand attributed to government spending induces an increase in price inflation in the following year.

The economy in Turkey responds to the monetary stimulus with a lag. Hence, the transmission mechanism of monetary policy appears less effective, compared with fiscal policy, in providing an immediate stimulus to economic conditions during the current year. Accordingly, all real variables, including output growth, consumption growth, investment growth, export growth, and import growth respond negatively to an increase in monetary growth in the current period. Nonetheless, there is an inflationary contemporaneous effect with respect to an increase in monetary growth. The stimulus effect of monetary growth is transmitted in the following year, as evident by the increase in real growth of output and consumption. Nonetheless, the inflationary effect of monetary growth persists beyond the current period.

Turkey is surrounded by a number of oil-producing countries (Iran and Arab Gulf countries). Hence, there is evidence of a positive spillover effect from the increase in the oil price on real growth of output, consumption, and investment in Turkey. Concurrently, price inflation slows down, despite the increase in the oil price. The inflationary effect of the increase in oil price is evident in the following year. Through this channel, there is a reduction in real export growth in response to an increase in the oil price in the previous year.

Consistent with theory's prediction, anticipated exchange rate appreciation determines the supply side of the economy in Turkey. Anticipated appreciation generates expectations of a loss in competitiveness. Subsequently, producers shrink the output supply, which is inflationary. Concurrently, there is a reduction in real demand for investment and exports in the face of anticipated appreciation of the real effective exchange rate. The contractionary effects of anticipated appreciation on real growth and real investment demand persist into the following year.

Consistent with theory's predictions, conflicting channels on the demand and supply sides render the effect of unanticipated currency appreciation insignificant in Turkey. The only exception is the lagged significant effect of unanticipated appreciation that counters price inflation. Unanticipated appreciation decreases the cost of imported inputs and, therefore, price inflation in the following year.

There is a strong evidence of asymmetry in the effects of exchange rate shocks on the Turkish economy. More precisely, unanticipated depreciation appears to have more important effects, compared with unanticipated appreciation, on the Turkish economy. The significant effects of unanticipated depreciation appear to be lagged, however. Specifically, unanticipated depreciation (through the cost of imported goods) decreases real output growth and the growth of real private consumption and investment. Unanticipated depreciation increases the growth of real exports in the following year, as the improved competitiveness stimulates demand for Turkish exports. 
The Turkish economy, over the time span under investigation (1980-2004), has experienced several structural breaks that mark important political and economic events. In 1988, there was an economic crisis that resulted in a significant decrease in real output growth and a significant increase in price inflation. In 1992, developments related to the Gulf crisis led to an increase in price inflation, coupled with an increase in investment growth. In 1996, integration into the Customs Union resulted in a significant increase in exports and imports, along with a significant decrease in price inflation. Finally, the earthquake of 1996 resulted in a reduction in the real growth of output and in both private consumption and investment.

Overall, the analysis provides interesting insights into determinants of cyclicality in economic activity in Turkey. Anticipated depreciation may be stimulating of real growth, albeit it may prove inflationary. Domestic policies (contractionary fiscal and monetary policies) could be used to counter the inflationary effects of depreciation. Moreover, variability of unanticipated exchange rate shocks could be detrimental, given asymmetry in the effects of the exchange rate. Higher variability of the real effective exchange rate around its anticipated value has a net negative effect on the trends of real growth of output, private consumption, and investment in Turkey. While adhering to a flexible exchange rate policy, managing fundamentals to reduce excessive volatility impinging on the economic system over time should top the policy agenda in Turkey.

\section{Acknowledgments}

The authors thank an anonymous referee for valuable comments on an earlier draft of the paper. The views expressed in this paper are those of the authors and should not be attributed to the International Monetary Fund, its Executive Board, its management, or to the State Planning Organization in Turkey.

\section{Appendix A. Figures on Turkey}

Figs. A1-A10.

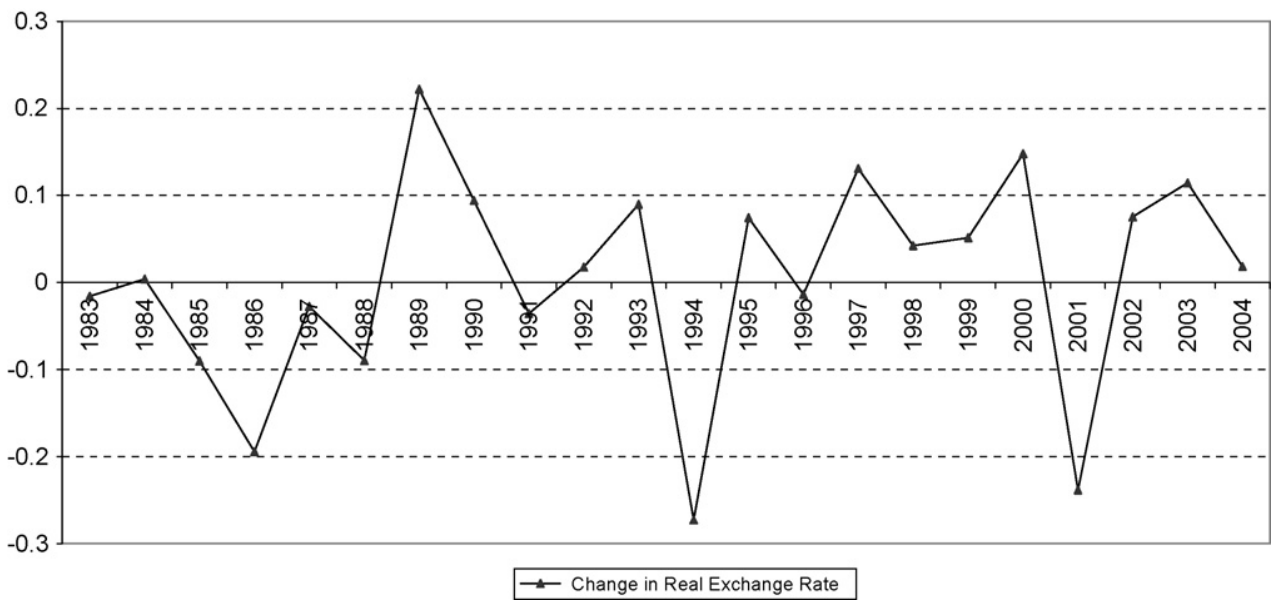

Fig. A1. Annual change in real exchange rate. 


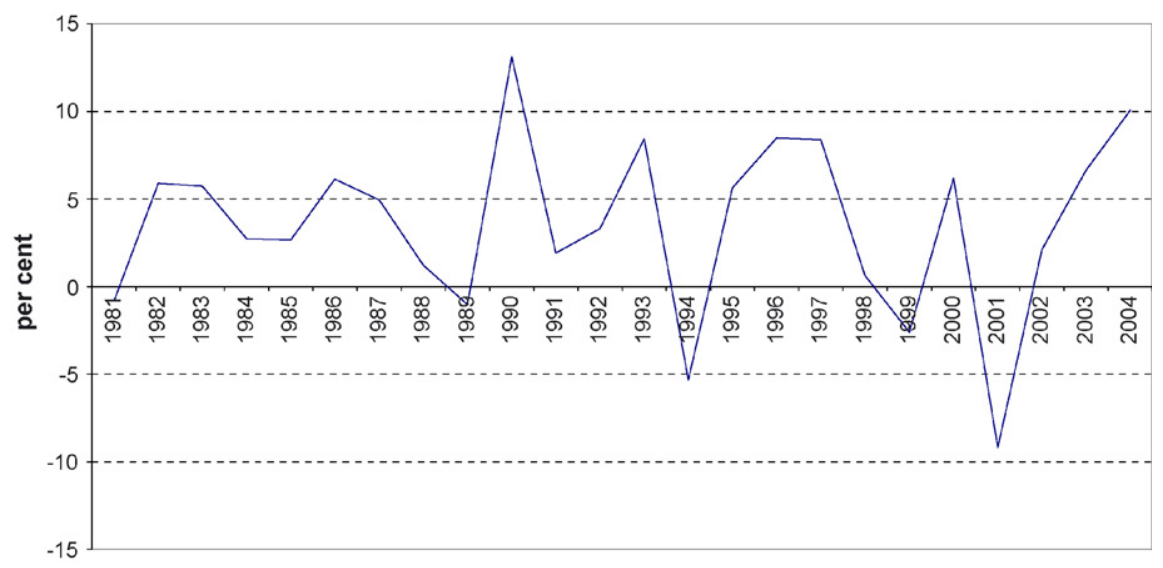

Fig. A2. Annual change in inflation.

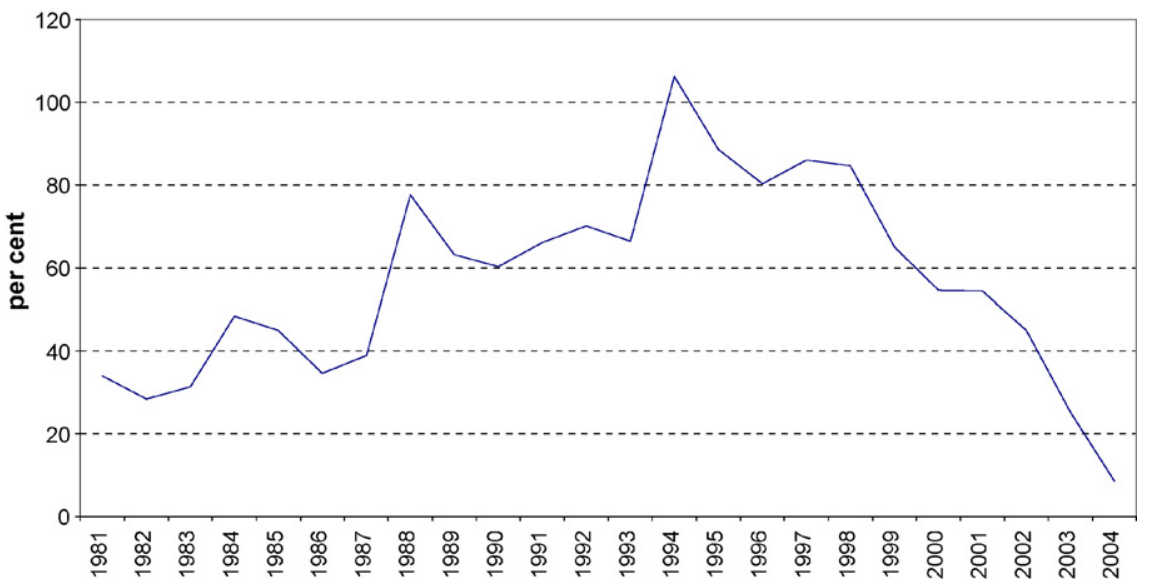

Fig. A3. Annual change in real consumption.

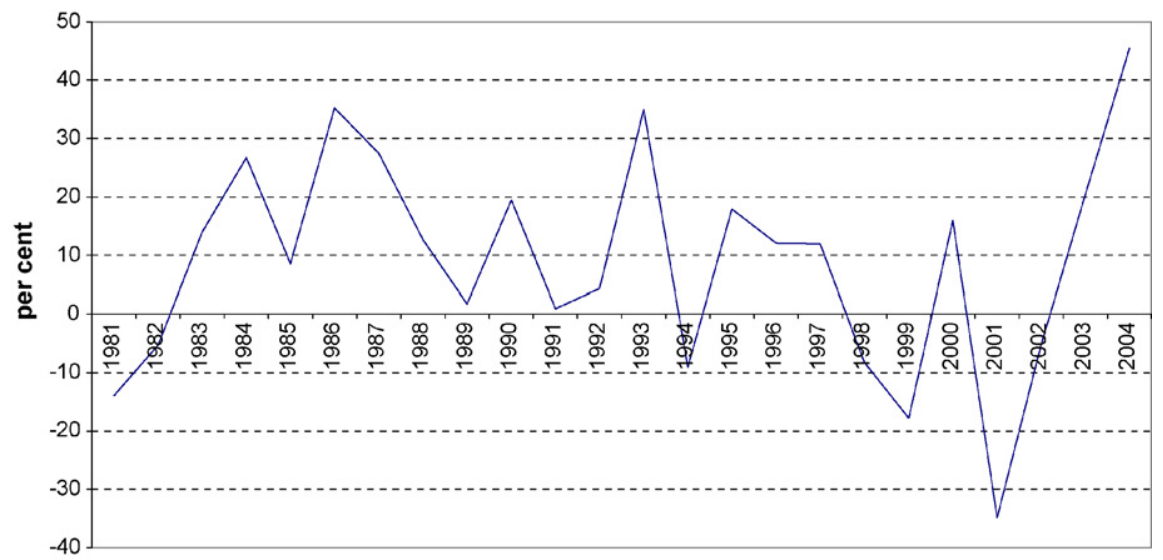

Fig. A4. Annual change in real investment. 


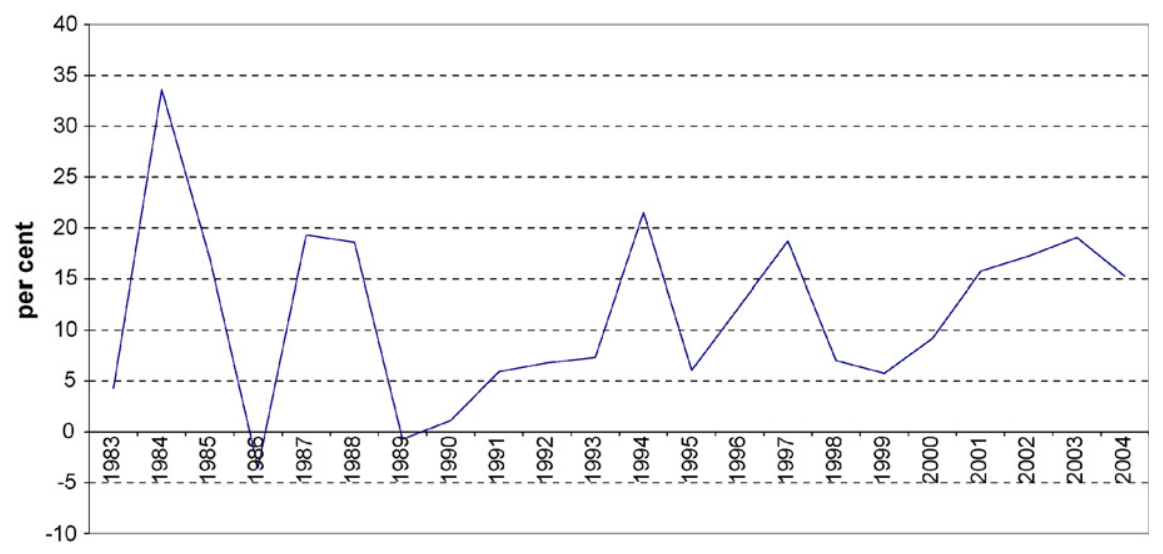

Fig. A5. Annual change in real exports.

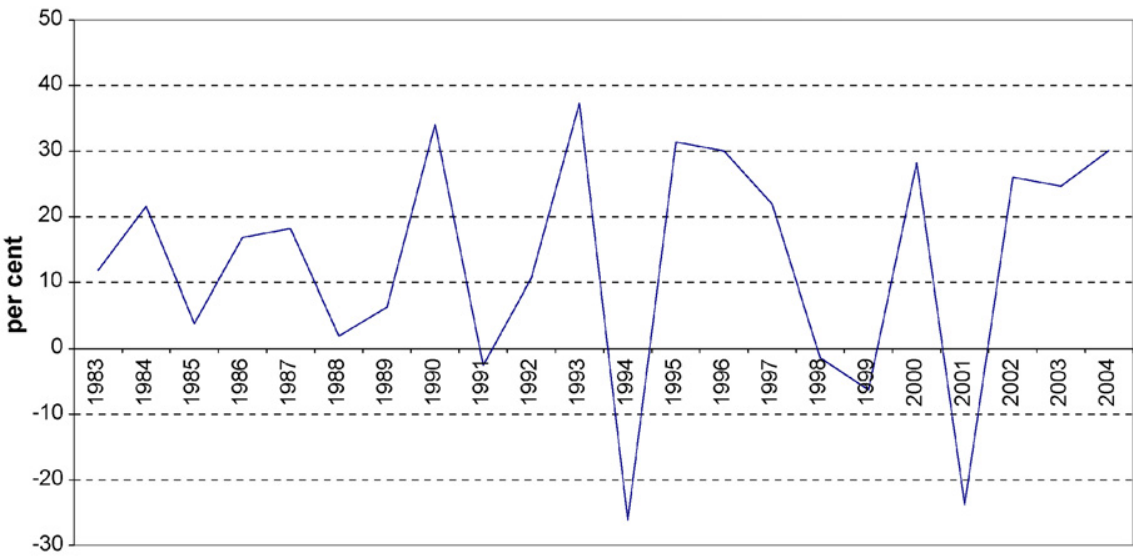

Fig. A6. Annual change in real imports.

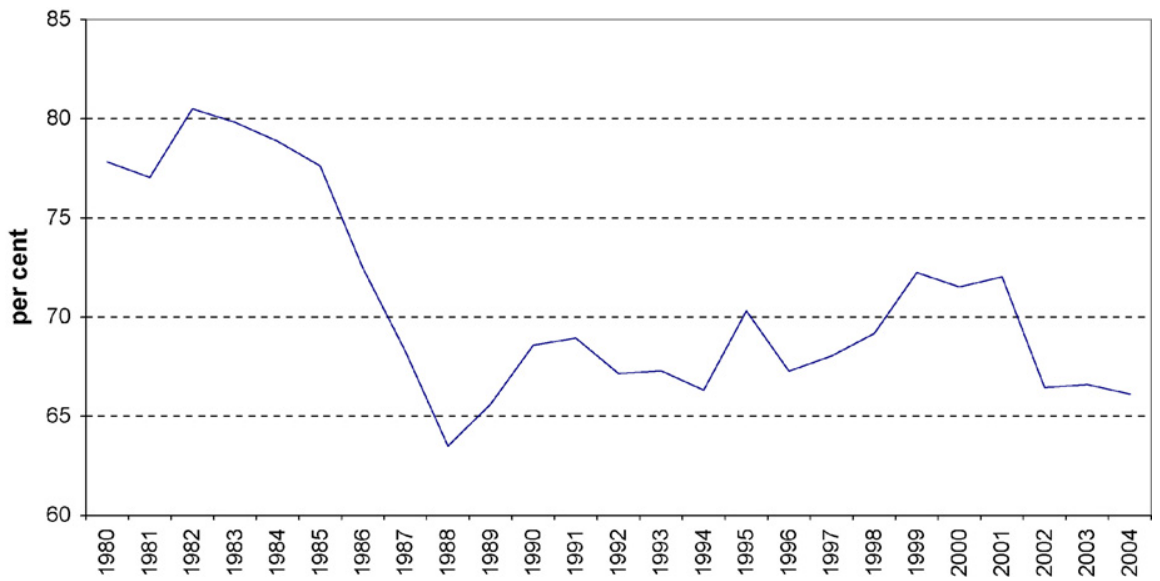

Fig. A7. Share of private consumption in GDP. 


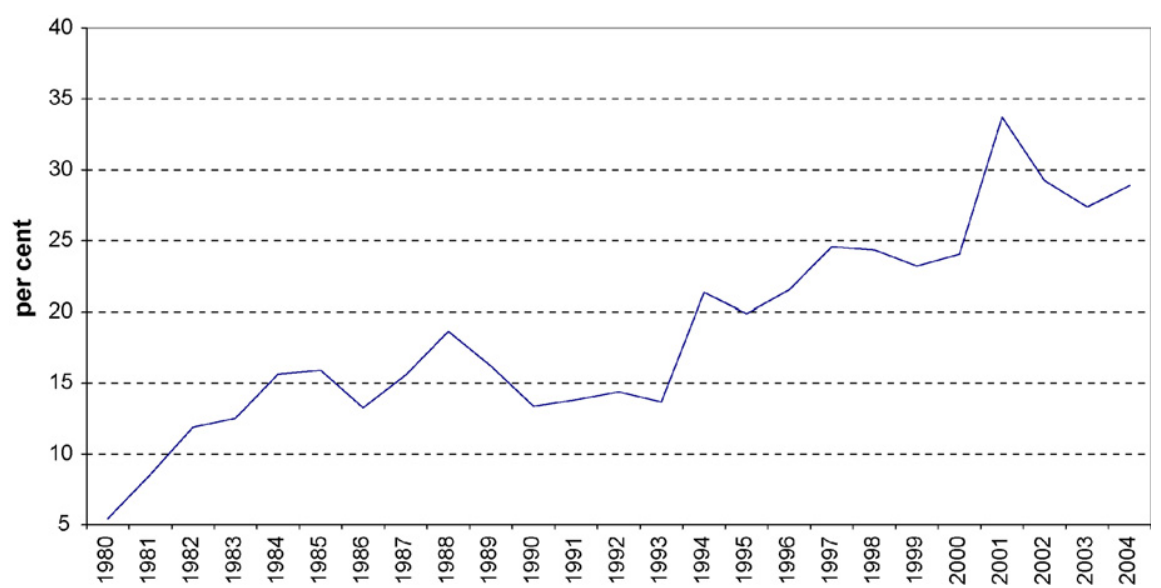

Fig. A8. Share of private investment in GDP.

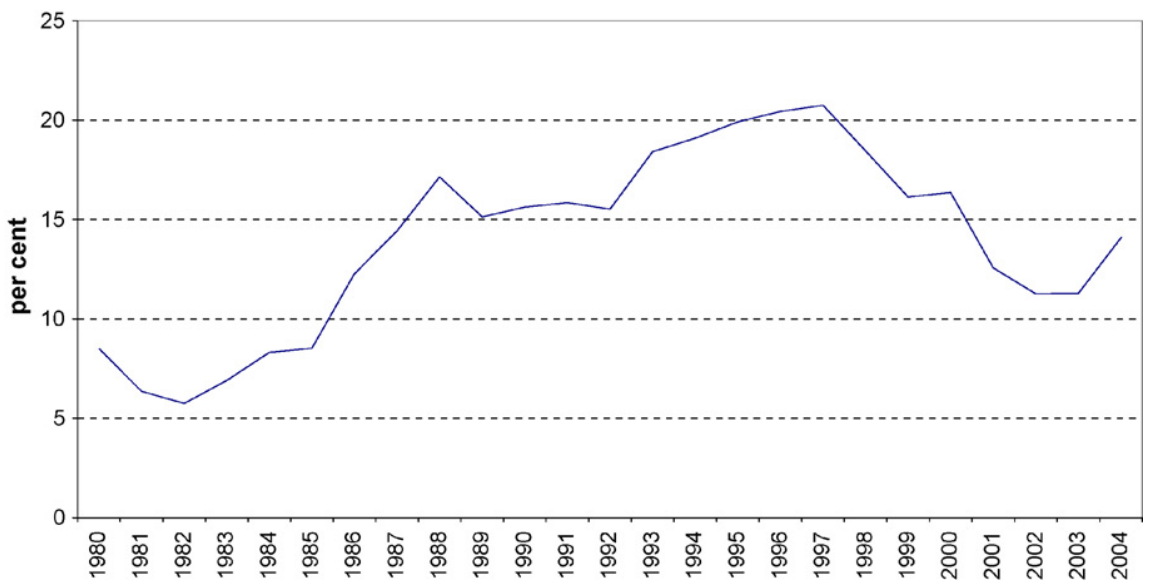

Fig. A9. Share of exports in GDP.

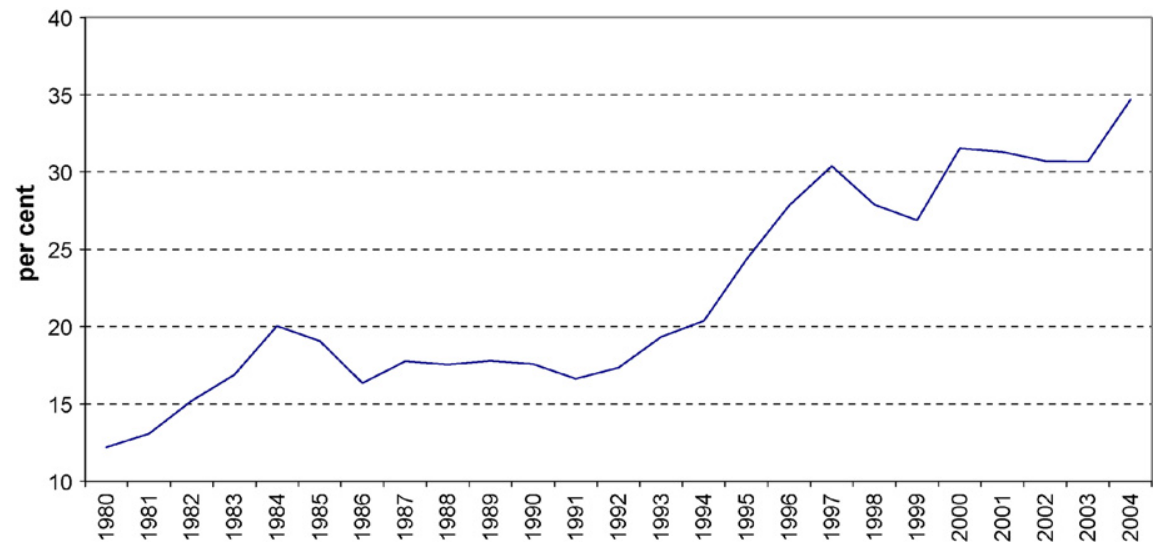

Fig. A10. Share of imports in GDP. 


\section{Appendix B. Data set}

The analysis is based on an annual data set which covers the 1980-2004 period.

Real exchange rate is the trade weighted real exchange rate from Central Bank of Republic of Turkey (CBRT).

Price inflation is the official consumer price index of CBRT.

Money is represented by M2Y.

Real output is GDP in 1987 prices which is announced by the State Institute of Statistics of Turkey.

Real private consumption, real government consumption, and real investment are from the State Institute of Statistics in 1987 prices.

Exports and imports are taken from the balance of payments statistics of the CBRT. The figures are deflated by the price index and real figures are used in the analysis for consistency purposes.

Trade balance is the difference between exports and imports, and openness is the ratio of the sum of exports and imports to GDP.

Finally, Energy prices are taken from the International Energy Agency Yearbook.

\section{References}

Agenor, P. (1991). Output, devaluation and the real exchange rate in developing countries. Weltwirtschaftliches Archive, Band, 127, 19-41.

Bahmani, M. (1991). Are devaluation contractionary in LDCs? Journal of Economic Development .

Barbone, L., \& Rivera-Batiz, F. (1987). Foreign capital and the contractionary impact of currency devaluation, with an application to Jamaica. Journal of Development Economics, 26, 1-15.

Bruno, M. (1979). Stabilization and stagflation in a semi-industrialized economy. In R. Dornbusch \& J. Frankel (Eds.), International Economic Policy. Baltimore, MD: Johns Hopkins University Press.

Buiter, W. H. (1990). International macroeconomics. Oxford University Press.

Cooper, R. N. (1971). "Currency Devaluation in Developing Countries," Essays in International Finance, No. 86, International Finance Section, Princeton University.

Cover, James P. (1992). Asymmetric effects of positive and negative money supply shocks. Quarterly Journal of Economics, 107(4), 1261-1282.

Diaz-Alejandro, C. F. (1963). Note on the impact of devaluation and redistributive effect. Journal of Political Economy, $71,577-580$.

Dornbusch, R. (1988). Open economy macroeconomics, 2nd ed., New York.

Edwards, S. (1986). Are devaluations contractionary? Review of Economics and Statistics, 23, 83-140.

Froot, K. A., \& Klemperer, P. D. (1989). Exchange rate pass-through when market share matters. American Economic Review, 79, 637-654.

Goldberg, P. K. (1995). Product differentiation and oligopoly in International Markets: The case of the US automobile industry. Econometrica, 63, 891-951.

Guittian, Manuel (1976). The effects of changes in the exchange rate on output, prices, and the balance of payments. Journal of International Economics, 6, 65-74.

Gylfason, T., \& Radetzki, (1991). Does devaluation make sense in least developed countries? Economic Development and Cultural Change, 40(1), 1-25.

Gylfason, Thorvaldur, \& Schmid, Michael. (1983). Does devaluation cause stagflation? Canadian Journal of Economics, 16(4), 641-654.

Hanson, James A. (1983). Contractionary devaluation, substitution in production and consumption, and the role of the labor market. Journal of International Economics, 14, 179-189.

Hirschman, A. O. (1949). Devaluation and the trade balance: A note. Review of Economics and Statistics, 31, 50-53.

Hoffmaister, A., \& Vegh, C. (1996). Disinflation and the recession now versus recession later hypothesis: Evidence from Uruguay. IMF Staff Papers 43. 
Kamin, S. B., \& Rogers, J. H. (2000). Output and the real exchange rate in developing countries: An application to Mexico. Journal of Development Economics, 61, 85-109.

Kandil, M., \& Mirzaie, I. (2002). Exchange rate fluctuations and disaggregated economic activity in the US: Theory and evidence. Journal of International Money and Finance, 21, 1-31.

Kandil, M., \& Mirzaie, I. (2003). The effects of dollar appreciation on sectoral labor market adjustments: Theory and evidence. Quarterly Review of Economics and Finance, 43(1), 89-117.

Knetter, M. M. (1989). Price discrimination by US and German Exporters. American Economic Review, 79, 198-210.

Krugman, P., \& Taylor, L. (1987). Contractionary effects of devaluation. Journal of International Economics, 8, 445-456.

Kwiatkowski, Denis, Phillips, Peter C. B. , Schmidt, Peter, \& Shin, Yongcheol. (1992). Testing the null hypothesis of stationarity against the alternative of a unit root: How sure are we that economic time series have a unit root? Journal of Econometrics, 54, 159-178.

Lizondo, S., \& Montiel, P. J. (1989). Contractionary Devaluation in Developing Countries: Analytical Overview. IMF Staff Papers, 36, 182-227.

Marston, R. C. (1990). Pricing to Market in Japanese Manufacturing. Journal of International Economics, 29, $217-236$.

Meade, J. E. (1951). The theory of International Economic Policy, I: The balance of payment. Oxford: Oxford University Press.

Mendoza, E. G. (1992). The effect of macroeconomic shocks in a basic equilibrium framework. IMF Staff Papers, 39(4), 855-889.

Rogers, J., \& Wang, P. (1995). Output, inflation, and stabilization in a small open economy: Evidence from Mexico. Journal of Development Economics, 46(2), 271-293.

Solimano, A. (1986). Contractionary devaluation in the Southern Cone: The case of Chile. Journal of Development Economics, 23, 135-151.

van Wijnbergen, S. (1989). Exchange rate management and stabilization policies in developing countries. Journal of Development Economics, 23, 227-247. 